\title{
Microarray Technology
}

National Human Genome Research Institute (NHGRI)

\section{Source}

National Human Genome Research Institute (NHGRI). Microarray Technology.

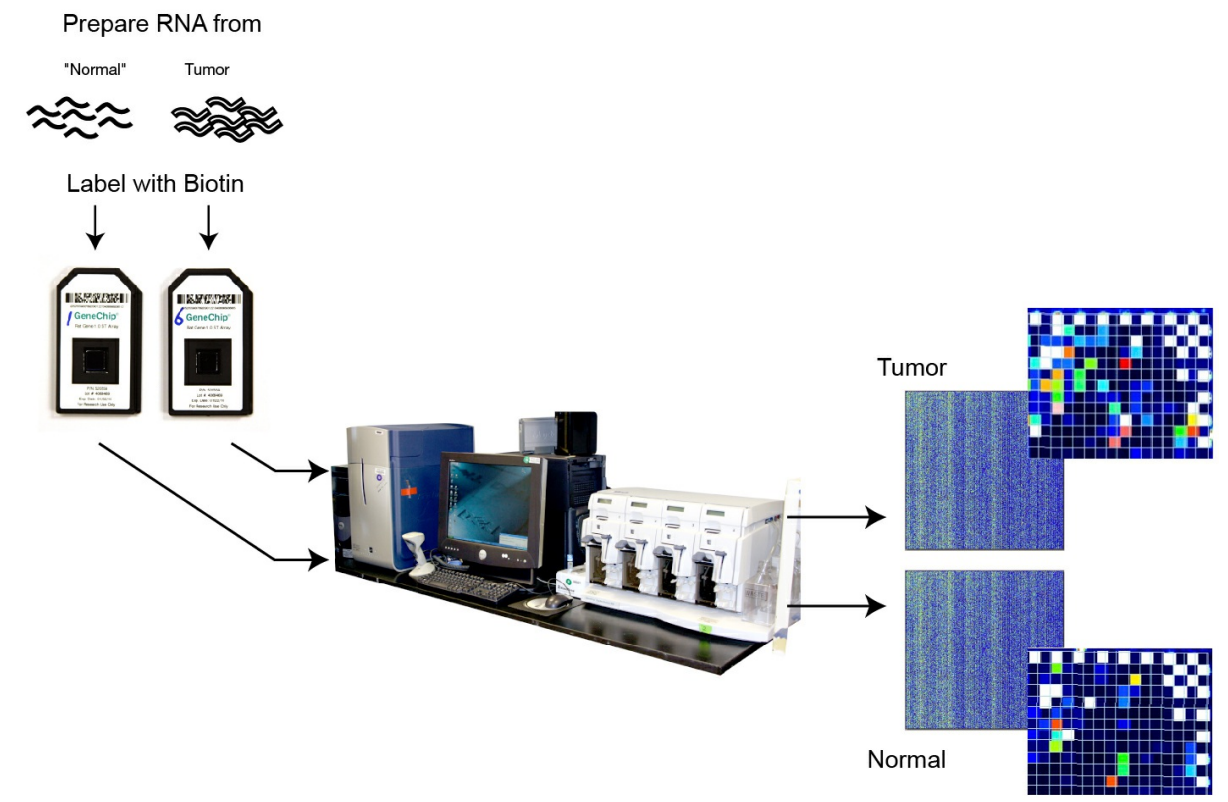

Microarray technology is a developing technology used to study the expression of many genes at once. It involves placing thousands of gene sequences in known locations on a glass slide called a gene chip. A sample containing DNA or RNA is placed in contact with the gene chip. Complementary base pairing between the sample and the gene sequences on the chip produces light that is measured. Areas on the chip producing light identify genes that are expressed in the sample. 